\title{
The effect of balance training on ankle proprioception in patients with functional ankle instability
}

Tarang K Jain ${ }^{*}$, Clayton N Wauneka ${ }^{2}$, Wen Liu' ${ }^{1,2}$

From 4th Congress of the International Foot and Ankle Biomechanics (i-FAB) Community

Busan, Korea. 8-11 April 2014

\section{Background}

Approximately $40-70 \%$ of individuals who suffer an ankle sprain report residual symptoms 6 weeks to 18 months post injury [1]. Balance training is often the first choice of treatment in patients with functional ankle instability (FAI); however the effect of balance training on the ankle proprioceptive sensation in these patients is debatable [2].

\section{Purpose}

To examine the effect of 4-week balance training intervention on self-reported ankle instability using Cumberland ankle instability tool questionnaire (CAIT) and ankle joint position sense (JPS) using joint position-reposition test in patients with FAI.

\section{Methods}

Twenty-four recreationally active patients with unilateral FAI were randomized to either the control $(\mathrm{n}=12,34.6$ \pm 9.04 years, CAIT score $=13.9 \pm 4.3)$ or experimental $(n=12$, $33.8 \pm 6.4$ years, CAIT score $=13.4 \pm 3.3$ ) group. Patients in the experimental group were trained on the affected limb using static and dynamic balance components with

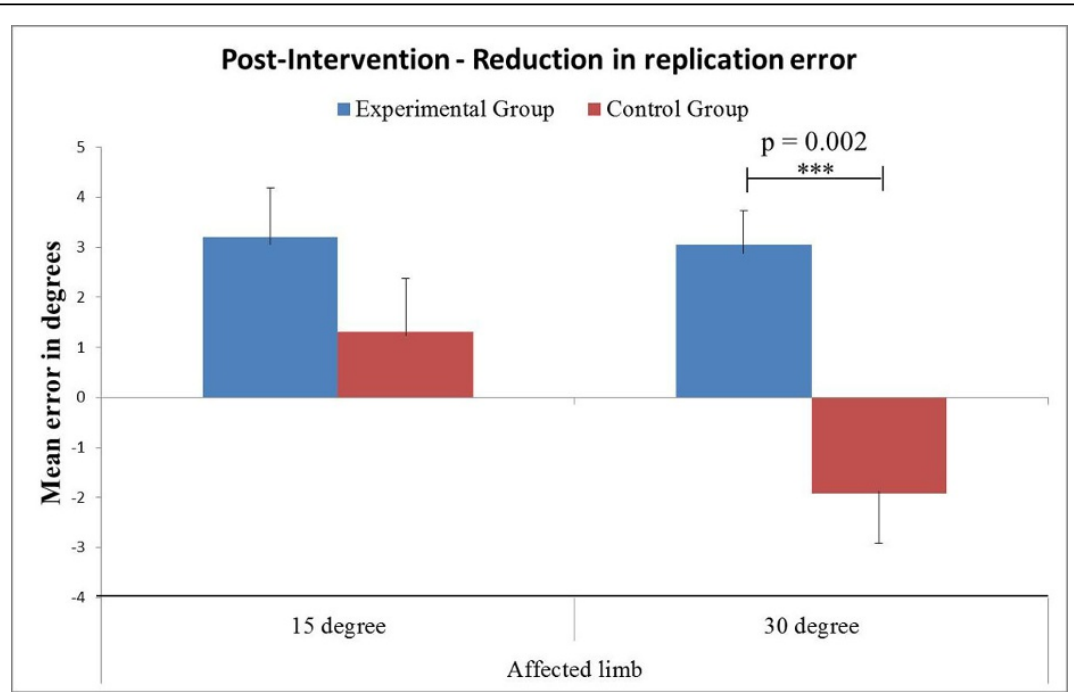

Figure 1 Reduction in mean replication error in both the groups following balance training intervention

\footnotetext{
* Correspondence: tjain@kumc.edu

${ }^{1}$ Physical Therapy and Rehabilitation Science, University of Kansas Medical

Center, Kansas City, KS, 66160, USA

Full list of author information is available at the end of the article
}

(c) 2014 Jain et al; licensee BioMed Central Ltd. This is an Open Access article distributed under the terms of the Creative Commons 
Biodex balance stability system. CAIT questionnaire was administered at baseline and 6-week post-intervention. The passive ankle JPS at 15 and 30 degrees of ankle inversion on the affected and unaffected limbs was measured at baseline and 4-week post-intervention using Biodex dynamometer. CAIT questionnaire score and mean error in angular displacement at baseline and post-intervention were compared using two-tailed paired Student $\mathrm{t}$ tests.

\section{Results}

At baseline, CAIT questionnaire scores were similar between the two groups. There was a significant side-toside difference in the mean error at $30^{\circ}(4.1 \pm 2.6$ vs. 2.5 $\pm 2.0, \mathrm{p}=0.03,95 \% \mathrm{CI}[0.170,3.024])$ of ankle inversion. Following balance training, the experimental group showed significant improvement in CAIT questionnaire score $(22.3 \pm 2.5, \mathrm{p}=0.001,95 \%$ CI $[2.983,9.183])$. The experimental group also showed significant reduction in mean error on the affected limb following intervention at both $15^{\circ}(1.9 \pm 1.4, \mathrm{p}=0.008,95 \% \mathrm{CI}[-5.376,-1.013])$ and $30^{\circ}(1.4 \pm 1.2, \mathrm{p}=0.001,95 \% \mathrm{CI}[-4.531,-1.580])$ of ankle inversion. When compared to the affected limb in the control group, affected limb in the experimental group demonstrated significant reduction in mean error at $30^{\circ}(\mathrm{p}=0.002)$ but not at $15^{\circ}$ of ankle inversion following balance training intervention (Figure 1).

\section{Conclusion}

The 4-week balance training program was effective in reducing the self-reported ankle instability and improving the deficit of ankle joint position sense in patients with FAI.

Level of evidence: Therapy, $2 \mathrm{~b}$

ClinicalTrials.gov Identifier: NCT00703456

Supported by NIH Grant R21 AR062205 and Kansas Partners in Progress, Inc.

\footnotetext{
Authors' details

${ }^{1}$ Physical Therapy and Rehabilitation Science, University of Kansas Medical Center, Kansas City, KS, 66160, USA. Bioengineering Graduate Program, University of Kansas, Lawrence, KS, 66405, USA.
}

Published: 8 April 2014

\section{References}

1. Yeung MS, et al: An epidemiological survey on ankle sprain. $\mathrm{Br} J$ Sports Med 1994, 28(2):112-6.

2. Ashton-Miller JA, et al: Can proprioception really be improved by exercises? Knee Surg Sports Traumatol Arthrosc 2001, 9(3):128-36.

doi:10.1186/1757-1146-7-S1-A37

Cite this article as: Jain et al:: The effect of balance training on ankle proprioception in patients with functional ankle instability. Journal of Foot and Ankle Research 2014 7(Suppl 1):A37.

\section{Submit your next manuscript to BioMed Central} and take full advantage of:

- Convenient online submission

- Thorough peer review

- No space constraints or color figure charges

- Immediate publication on acceptance

- Inclusion in PubMed, CAS, Scopus and Google Scholar

- Research which is freely available for redistribution

Submit your manuscript at www.biomedcentral.com/submit 